\title{
Catch-up Strategy of Close Followers__-Research on Path of Value Reconstruction within Value Network
}

\author{
Linhao Han $^{1, a^{*}}$ and Dong Wang ${ }^{2, b}$ \\ ${ }^{1}$ Wuhan University of Technology, China \\ ${ }^{2}$ Wuhan University of Technology, China \\ a1052244186@qq.com, b602819824@qq.com
}

Keywords: Value network; Value reconstruction; Follow scene; Catch-up strategy

\begin{abstract}
For the early stages of the industry's product lifecycle, following the example of the rapid re-entry of the market through the value of the enterprise will foster market competitiveness. This study attempts to explore the viable path of value reconstruction of Baosteel through case study[1]. The path breaks the limitations of the original internal innovation of the enterprise, placing value innovation, understanding, creation and delivery in a network system. At present, the research on product value innovation focuses on internal innovation, and the research on external value network acquisition of innovation source is rare.
\end{abstract}

\section{Introduction}

Customer-oriented product innovation concept has been deeply supported, but the success of product innovation is rare[2], which lies in the lack of a good path that can learn from the experience so that the value of the delivery process has become unimpeded, and ultimately get recognition from the consumer. From Nokia's heyday to the growth of Huawei's private technology business leaders, which are reflected in the industry's unique technology grafting, transplantation and delivery.

Thus, this paper explores three questions by fulfilling the value refactoring enterprise which is relying on the value network successfully: 1 . How to realize the value catchment rather than the low price competition through the reconstruction of the value? 2. What is the support role of value network for value beyond? 3 . What is the unique interaction of the value network?

Value reorganization is to enhance the use of value and added value, improve product use convenience by grafting, transplantation, reorganization and other methods[3]. As for the understanding, creating and delivering customer value in the process of achieving corporate profits and the purpose of market expansion, the process is a network of value throughout the industrial ecosystem. Value chain perspective is to break the value of the traditional value chain and the value of the activities of the separation of the mechanical model, the value of activities around the reconstruction of the original value chain to create value[4].

\section{Theory Development and Propositions}

The study of value reconstruction in academia can be divided into two directions: vertical reconstruction based on value network and reconstruction of value based on business modularization.

Early research suggests that the value of the value network reconstruction emphasizes the creation of a "win-win strategy" in the enterprise's strategy, in which an organization and an organic "symbiotic" network are formed among the organizations[5]. This network is the earliest research model of the enterprise value network[6]. So far, the value of the network has been applied by more and more enterprises in strategic management leve. The enterprise value network is based on the customer value as the strategic starting platform, using mergers and acquisitions, strategic alliances and other means to build the value creation and value management system [7], and the essence of the value network is specialized in the division of labor production service model through a certain value transfer mechanism. In the corresponding framework of governance, due to the different 
stages of the value chain and relative curing, the model has a special asset attributes and together.

Closely following the enterprise to achieve high value, you need to reconstruct value in the value of refactoring. According to the consumer's continuous learning and growth to identify customer value. To provide consumers with products that are in line with the market, the completion of the value in the delivery process will be achieved.

Accordingly, three propositions are proposed:

Proposition 1: Followers must catch up market leader by value reconstruction.

Proposition 2: To break through technical barriers must meet the fast, safe, low-risk conditions.

Proposition 3: Followers achieve value delivery and providing solutions, and they firstiy need to use value networks to understand customer value and thus create value

\section{Method}

Measurement. Case study is an empirical research method through the reality of a complex phenomenon in-depth and comprehensive analysis, in order to reveal the nature and causes of things. In the case of a single case study, employing the main rule of the copy [8], so that the case can be verified in other circumstances.

The Choice of Case. This article mainly focuses on Baosteel Group's product innovation. The Group adopt the application of the oil industry's mining machinery - shield machine, and established a partnership with four machine factory, which will be applied to the steel industry, steel technology, the use of their own value network for cross-industry value reconstruction can meet customer needs. The value refactoring needs to be done more efficiently in the value network, and the value network provides a good platform and reference value for the value reconstruction of the enterprise.

Reliability and Validity. Based on the value of the network within which we refactor the path theory model, the use of value network to achieve the value of the successful reconstruction of a typical enterprise is based on the exploratory study. To collect some econd-hand information of the typical enterprise for research and analysis, the data mainly from the enterprise's annual report, brochures, networks and journal articles and so on. To ensure the reliability and validity of information collection, this paper attempts to use a variety of methods, as far as possible the interview records and internal reports, journals and other links to strengthen the evidence between the mutual confirmation.

\section{Case Analysis}

Baosteel supplier's participation in the value of reconstruction. Baosteel acknowledges "create value for the user" as the business philosophy, and they always create new products for users. Such as FAW-Volkswagen CA1092 series of trucks suffer from high cost, fuel consumption. According to the user selection requirements, Baosteel R\&B personnels select the $1550 \mathrm{~mm}$ cold-rolled high-strength plate to replace the original material, the cab 44 main parts to Baosteel new test high-strength cold-rolled plate replace steel manufacturing, to reduce material consumption and reduce Car weight, reduce fuel consumption and emissions of the purpose. 44 major parts of all manufacturing success, 5 prototype platform with mass production conditions.

Baosteel Group in the process of cooperation with Xiangyang Boya through the application of the oil industry, mining machinery - shield machine, the oil exploration technology applied to the steel industry, using their own value network for cross-industry value reconstruction, making the enterprise meet customer needs at the same time. 


\section{Coding Classification.}

Table1. Coding classification in case study

\begin{tabular}{|c|c|c|c|}
\hline $\begin{array}{l}\text { First-level } \\
\text { coding }\end{array}$ & $\begin{array}{l}\text { Secondary } \\
\text { coding }\end{array}$ & Frequency & Typical references \\
\hline \multirow[t]{4}{*}{$\begin{array}{l}\text { Customer } \\
\text { value } \\
\text { demands }\end{array}$} & $\begin{array}{l}\text { Analysis of } \\
\text { customer } \\
\text { needs }\end{array}$ & 20 & $\begin{array}{l}\text { Baosteel requires a specific price standard to } \\
\text { request the supplier, from the actual and feel these } \\
\text { two aspects to consider the customer can accept } \\
\text { the purchase price. }\end{array}$ \\
\hline & $\begin{array}{l}\text { Customer } \\
\text { knowledge }\end{array}$ & 15 & $\begin{array}{l}\text { Baosteel Marketing Department to understand the } \\
\text { customer's purchase motivation, purchase habits, } \\
\text { purchase conditions, purchase decisions, etc.; } \\
\text { domestic different customers for different } \\
\text { psychological conditions, to take different } \\
\text { marketing strategies. }\end{array}$ \\
\hline & $\begin{array}{l}\text { Customer } \\
\text { Satisfaction }\end{array}$ & 21 & $\begin{array}{l}\text { Customer trust is the customer of the brand } \\
\text { products and the brand has the trust of the brand, } \\
\text { they can rationally face the success of brand } \\
\text { enterprises and adverse. }\end{array}$ \\
\hline & $\begin{array}{l}\text { business } \\
\text { performance }\end{array}$ & 18 & $\begin{array}{l}\text { The operating plan department sells sales, sales } \\
\text { growth rate, gross profit, gross profit margin, } \\
\text { gross profit growth rate, loss rate, other income, } \\
\text { other income growth rate, consolidated gross } \\
\text { profit margin, labor cost, sales ratio, operating } \\
\text { expenses, Net interest rate, inventory turnover } \\
\text { rate, return on investment, return on assets and so } \\
\text { on. }\end{array}$ \\
\hline \multirow[t]{3}{*}{$\begin{array}{l}\text { enterprise } \\
\text { value } \\
\text { demands }\end{array}$} & $\begin{array}{l}\text { Technological } \\
\text { innovation }\end{array}$ & 13 & $\begin{array}{l}\text { Baosteel's new technology, new equipment and } \\
\text { new technology in the fields of iron and steel } \\
\text { smelting, rolling technology, steel material, } \\
\text { electromechanical technology, refractory material, } \\
\text { energy, automation, instrumentation, chemical and } \\
\text { chemical inspection, comprehensive utilization } \\
\text { and environmental protection }\end{array}$ \\
\hline & $\begin{array}{l}\text { Integrate } \\
\text { business }\end{array}$ & 24 & $\begin{array}{l}\text { Baosteel will take this as an opportunity to further } \\
\text { increase business integration, such as the use of } \\
\text { listed companies platform, focus on the } \\
\text { development of core resources industry, improve } \\
\text { corporate governance structure, optimize the } \\
\text { ownership structure, fit the industry incubation } \\
\text { positioning, explore the industrial fund investment } \\
\text { model }\end{array}$ \\
\hline & $\begin{array}{l}\text { Brand } \\
\text { Building }\end{array}$ & 23 & $\begin{array}{l}\text { To implement the "fine }+ \text { scale" strategy to } \\
\text { achieve from steel to materials, from } \\
\text { manufacturing to service, from China to the global } \\
\text { transformation, from the steel industry to the } \\
\text { relevant multi-industry coordinated development, } \\
\text { are the urgent need for strong brand support }\end{array}$ \\
\hline
\end{tabular}

In this paper, only the final coding of the elements of the value reconstruction path is shown. In the specific operation, through the three members of the Baosteel data encoding, the similarities and differences between the code determines the basic rules of the study scenario. In this paper, we have 
extracted 28 codes related to binary interaction: partner management, market information acquisition, brand building, customer personalized management, capital investment and so on.

According to Org Z and other author's contribution to the analysis process(Org Z,2011), we initialize the number of entries for the statistics, and then the same higher level factors of the initial number of coding entries added, thus derived the importance of factors. This paper adopted this research method, the initial coding summarized in the previous text presented in the range of various elements of capacity, statistical initial encoding of the frequency of words determine the importance of factors.

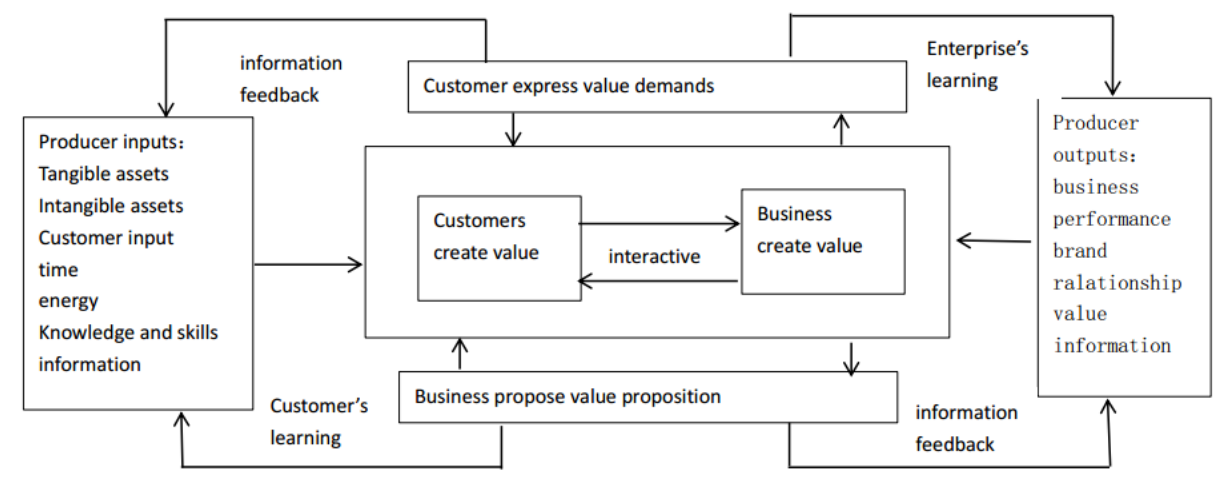

Figure 1. Illustration of structure of value demands between the customers and enterprise

\section{Explanation of Value Reconstruction Path Theory Model}

The Starting Point of the Value and the Operation Mechanism of the Network. In the enterprise value network system, we set benchmark customers that lead the customer as the starting point. According to the customer feedback information, suppliers in the value network can be long-term partners through the division of labor and professionalization of the best allocation of resources, or choose the industry's unique technology for value reconstruction.

Seeking value to Customers. Customer and business interaction can be divided into three dimensions: co-production, customer contact and service customization. Customer participation in the degree of new product development activities, reflects whether the customer in product innovation contribute their wisdom and strength that quantify the degree of involvement of customers involved in the development of new products and breadth of the depth[9]. Breadth refers to the scope of customer participation in the development, while the depth represents the degree of participation of customers in the development activities.

Collaborate with Suppliers to Innovate. Through the supplier channel, companies can get access to the value of the realization of the channels and programs, and through the integration of programs and technology, we'll find the point of value. Follow-up companies can establish strategic partnerships with the most outstanding upstream and downstream companies, they entrust these companies to create special value, and invest more environmental resources in more competitive areas. The ultimate goal is to use the system management model to minimize the cost of enterprise products into the market, making the greater profits[10].

\section{Conclusions and Limitations}

In this paper, we select the typical analysis of Baosteel in the case study, drawing the conclusion that the value of the value network is based on the value of the reconstruction path. In the early stages of the product, the corporation approach customers, understand the customer's willingness . Collecting the value of the source, and then satisfying customer demand in the value creation process. What's more, to find the source of technology from the supplier and obtain technology to achieve the program, resulting in the final requirements of the market after the product feedback is given to the customer. 
The shortcomings of this paper is that the choice of case study is too narrow, the lack of first-hand information on the proposition hinder us to supporting more dimensions. In the future study, we will focus more on the comprehensiveness of case data collection. For the value of the collection method, the key factors and the source of the method of analysis were studied. So we will make the system of value reconstruction more clear and clear.

\section{References}

[1] Xu Qingrui, Jiang Jian, Zheng Gang. The supplier participated in the research on technology innovation -- case analysis based on baosteel group [J]. Journal of China university of geosciences (social science edition), 2004, 4(6):6-9. [2]Bakker V. TRIANA : a control strategy for Smart Grids : forecasting, planning and real-time control[J]. University of Twente, 2017.

[3] Amit R, Zott C. Value Creation in E-Business[J]. Strategic Management Journal, 2001, 22(6/7):493-520.

[4] Clegg S, Schweitzer J, Whittle A, et al. Strategy Theory and Practice[M]. EP, 2017.

[5] Grönroos C, Voima P. Critical service logic: making sense of value creation and co-creation[J]. Journal of the Academy of Marketing Science, 2013, 41(2):133-150.

[6] Org Z. Measuring social value orientation[J]. Judgment \& Decision Making, 2011, 6(8):771-781.

[7] Árni Halldórsson, Hsuan J, Kotzab H. Complementary theories to supply chain management revisited - from borrowing theories to theorizing[J]. Supply Chain Management, 2015, 12(4):284-296.

[8] Yin R K. Case study research : design and methods[M]. Blackwell Science Ltd, 1994.

[9] Keller K L, Reinartz W. Creating enduring customer value[J]. Journal of Marketing, 2016, 80(6):págs. 36-68.

[10] Liu L L, Management S O. Industrial Heterogeneity,Technological Innovation and Enterprise Value[J]. Technoeconomics \& Management Research, 2016. 